\title{
THE FUTURE DIRECTION OF CYBEROLOGY
}

\author{
AHAMAD TARMIZI AZIZAN* \\ TAN TSE GUAN** \\ AHMAD RASDAN ISMAIL*** \\ NIK ZULKARNAEN KHIDZIR**** \\ ZUKERI IBRAHIM***** \\ TENH HOCK KUAN ${ }^{* * * * * *}$ \\ MOHAMAD SHAHFIK AFENDI ABDUL GHANI $I^{* * * * * * *}$ \\ MOHD HAFIZ FAIZAL MOHAMAD KAMIL********
}

\begin{abstract}
Abstrak
Objektif untuk kertas kajian ini ialah untuk membincangkan hala tuju masa depan dunia siberologi. lanya terdiri daripada tujuh kunci utama iaitu: 1) memfokuskan pada hala tuju masa depan infografik. 2) menerangkan kajian masa hadapan tentang kejuruteraan perisian. 3) Menerokai "storytelling" digital untuk masa akan datang. 4) Menerangkan trend masa hadapan dalam pengimejan berkomputer. 5) membongkarkan potensi permainan mobil di masa hadapan. 6) mendedahkan pembangunan masa depan sistem tutor pintar. Akhir sekali, 7) membincangkan tentang kajian masa depan tentang interaksi computer insan.
\end{abstract}

Kata kunci: Siberologi, Infografik, Kejuruteraan Periasian, "Storytelling" Digital, Pengimejan berkomputer, Permainan Mobil, Sistem Tutor Pintar, Interaksi Komputer Insan.

\footnotetext{
* Ketua Program Siberologi dan Pensyarah di Fakulti Teknologi Kreatif \& Warisan, Universiti Malaysia Kelantan (UMK).

** PhD dan Pensyarah Kanan di Fakulti Teknologi Kreatif \& Warisan, Universiti Malaysia Kelantan (UMK).

*** PhD,Profesor Madya dan Ketua Unit Pengurusan Persekitaran, Keselamatan Dan Kesihatan Pekerjaan, Universiti Malaysia Kelantan (UMK).

**** PhD dan Timbalan Dekan di Fakulti Teknologi Kreatif \& Warisan, Universiti Malaysia Kelantan (UMK)

***** Pensyarah di Fakulti Teknologi Kreatif \& Warisan, Universiti Malaysia Kelantan (UMK)

****** Pensyarah di Fakulti Teknologi Kreatif \& Warisan, Universiti Malaysia Kelantan (UMK).

******* Pensyarah di Fakulti Teknologi Kreatif \& Warisan, Universiti Malaysia Kelantan (UMK).

******* Pensyarah di Fakulti Teknologi Kreatif \& Warisan, Universiti Malaysia Kelantan (UMK).

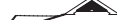




\begin{abstract}
The objective of this review paper is to discuss the future direction of cyberology. It consists of seven main parts. Part 1 of this review focused on future direction of infographics. Part 2 of this review presents the future study of software engineering. Part 3 explores the future of digital storytelling. Part 4 shows the future trends in computer generated imagery. Part 5 discovers future potential of mobile games. Part 6 reveals the future development of intelligent tutoring systems. Lastly, Part 7 discusses the future research of human computer interaction.
\end{abstract}

Keywords: Cyberology, Infographics, Software Engineering, Digital Storytelling, Computer Generated Imagery, Mobile Games, Intelligent Tutoring Systems, Human Computer Interaction

\footnotetext{
* Ketua Program Siberologi dan Pensyarah di Fakulti Teknologi Kreatif \& Warisan, Universiti Malaysia Kelantan (UMK).

** PhD dan Pensyarah Kanan di Fakulti Teknologi Kreatif \& Warisan, Universiti Malaysia Kelantan (UMK).

*** PhD,Profesor Madya dan Ketua Unit Pengurusan Persekitaran, Keselamatan Dan Kesihatan Pekerjaan, Universiti Malaysia Kelantan (UMK).

**** PhD dan Timbalan Dekan di Fakulti Teknologi Kreatif \& Warisan, Universiti Malaysia Kelantan (UMK)

***** Pensyarah di Fakulti Teknologi Kreatif \& Warisan, Universiti Malaysia Kelantan (UMK)

****** Pensyarah di Fakulti Teknologi Kreatif \& Warisan, Universiti Malaysia Kelantan (UMK).

******* Pensyarah di Fakulti Teknologi Kreatif \& Warisan, Universiti Malaysia Kelantan (UMK)

******** Pensyarah di Fakulti Teknologi Kreatif \& Warisan, Universiti Malaysia Kelantan (UMK). 


\subsection{Introduction}

The pace of global development has brought great change and transformation in their respective fields. Malaysia for one must consider talent to drive forward in its efforts to gain competitive advantage in the cyber world. Institutions of higher education are one of the main driving forces in developing and nourishing intellectual potential integrity to reform teaching and learning. Creativity and innovation in various fields of knowledge are essential to spur on the development of a country to ensure appropriate human capital to be mobilized and utilized in a broad spectrum of business and industry. Nowadays, the cyberspace has become a new trend of human lifestyle. The development of innovation in communication technology, mobile applications has turned a virtual world into a gradual reality by augmenting reality technology with the support of the visual art knowledge together with information and communication technologies, science, engineering and many other disciplines. Based on this awareness, this survey paper has been created to discuss the future technologies such as infographics, software engineering, digital storytelling, computer generated imagery, mobile games, intelligent tutoring systems and human computer interaction to generate new knowledge in the field of cyberology. 


\subsection{The Future Direction of Infographics}

To encounter infographics online is not uncommon these days. Infographics, of any information presented to its consumer in a graphic visual form, are increasingly used to grab attention and to facilitate both understanding and sharing of information. This trend does not seem to be ceased in the future and so infographics can only be expected to evolve into being even more efficient and user-friendly.

Infographics can significantly enhance any information in a number of ways. Infographics are attentiongrabbing. Users get automatically directed to the piece of information you want them to notice first, without running the risk of this information being lost in a sea of words. Infographics can transmit information much clearer than text in many cases. Graphs, schemes, charts, simple arrows: they all help clients to intake the information better and faster. The fact is that infographics can be easily shared on social media sites brings even more traffic to website and more attention to products or services.

Now that everyone loves them, early adopters and forward thinkers want to know what is next for the infographic. Is this just the beginning of a visual revolution, or have they already jumped the shark? This is an important question, especially for those who are making large investments in the medium, such as publishers and marketers. Is the Infographic dead? For now we are seeing the death of the novelty of infographics, not a decline in their value. The prevalence of infographics does not limit the opportunity to use the medium to create something of incredible quality and utility. The data boom and growing need to display complex concepts simply ensure that these opportunities for graphic visualizations will be plentiful in years to come.

Nowadays, infographics have been utilized for hundreds of years for various purposes, but have taken on a new face in the last few years, with a bit of help from the Internet and visual art (cyberology art). Static graphics are by far the most common medium, likely due to the fact that they are the easiest to create and host. This also affects the success of graphic distribution, as an image file that is simple to download, upload and re-post is more appealing to media outlets and blogs looking for fresh and interesting content to share on the web.

Infographics, unlike some people might think, are not only still images but also Infographics Video, Interactive Infographics, Motion Graphics Infographics (utilizing motion and animation), Real-Time Infographics, Cloud-Infographic and many more. While still images are definitely efficient in a great deal of circumstances, new media can prove to be a more effective way to communicate with viewers, clients and public. The newest trends around are beyond doubt. This is, beyond doubt, is the newest trend. So using these techniques cannot only make users understand the information better but also makes companies or owners seems more cutting-edge 
Nowadays, with the help from computers technology, internet and cyberology art will allow designers and developers to visualize multiple layers of data in a single interface, while providing a dynamic user experience for the viewer. While this is an increasingly serious limitation, the ease of development can often outweigh this consideration, and still net a very positive effect. The combination of illustration, data visualization and kinetic text to inform a viewer on a particular topic will provides an entirely different viewer experience; this medium is valuable in walking the viewer through an explanation or presenting an opinion by bringing the information to life for the desired audience.

How about the future of infographics? Over the past year, evolution in creating infographics has been done rapidly. Diverse applications are opening up the realm of what is possible and valuable through innovation. The prevalence of the mobile device and smartphone such as iPad and iPhone has fueled the desire for the development of interactivity in graphics viewable on these devices. Developers are utilizing programming language such as HTML, HTML5, XCode, and Java script to fulfill this desire, creating rich interactive viewable on these platforms. There is lots of space for improvement when it comes to infographics, no matter how advanced and useful they might already seem. Hence, no more hesitation: the future improvements must be turned into actions of today. Goh Ai Ching, the 27-year-old Chief Executive Officer of Penang-based Piktochart, a startup born in 2011, has surpassed RM1 million (US\$311,000) in revenue in August 2013, and claims to have over 350,000 users worldwide, $60 \%$ of whom are from the United States. Knowing all those benefits, I would imagine this trend will keep continuing to grow in future as well as more infographic form and opportunity is definitely to be seen and grab it as entrepreneurship opportunity in the future.

\subsection{The Future Direction of Software Engineering}

The term "Software Engineering" was first used in 1968 as a title for the world's first conference on Software Engineering, sponsored and facilitated by NATO. The conference was attended by international experts on software who agreed on defining best practices for software grounded in the application of engineering. The result of the conference is a report that defines how software should be developed [i.e., software engineering foundations] (Peter Naur and Brian Randell, 1st Conference on Software Engineering Report, 1968).

The discipline of Software Engineering was coined to address poor quality of software, get projects exceeding time and budget under control, and ensure that software is built systematically, rigorously, measurably, on time, on budget, and within specification. Engineering already addresses all these issues, hence the same principles used in engineering can be applied to software. The widespread lack of best practices for software at the time was perceived as a "software crisis" (Sommerville, 2008).

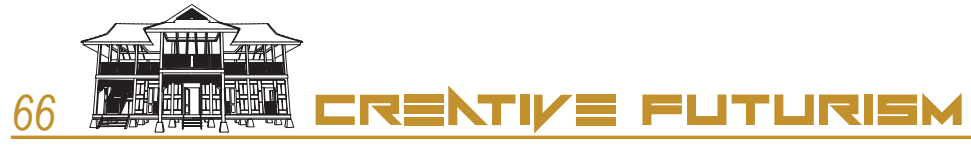


Barry W. Boehm documented several key advances to the field in his 1981 book, 'Software Engineering Economics' (Boehm (1981). In 1984, the Software Engineering Institute (SEI) was established as a federally funded research and development center headquartered on the campus of Carnegie Mellon University in Pittsburgh, Pennsylvania, United States. Watts Humphrey founded the SEI Software Process Program, aimed at understanding and managing the software engineering process. His 1989 book, Managing the Software Process, asserts that the Software Development Process can and should be controlled, measured, and improved. The Process Maturity Levels introduced would become the Capability Maturity Model Integration for Development (CMMi-DEV), which has defined how the US Government evaluates the abilities of a software development team.

The modern generally accepted practice for Software Engineering has been cataloged as a Guide to the Software Engineering Body of Knowledge (SWEBOK) which has become an internationally accepted standard ISO/IEC TR 19759:2005.

The potential future growth of Software Engineering Sub-Dicipline in order to produce the best quality of software system as well as software digital content. Following are the related Sub-discipline that for the field of Software Engineering (Abran et al. 2004):

- Requirements engineering: The elicitation, analysis, specification, and validation of requirements for software.

- Software design: The process of defining the architecture, components, interfaces, and other characteristics of a system or component. It is also defined as the result of that process.

Software construction: The detailed creation of working, meaningful software through a combi nation of coding, verification, unit testing, integration testing, and debugging.

- Software testing: The dynamic verification of the behavior of a program on a finite set of test cases, suitably selected from the usually infinite executions domain, against the expected be havior.

- Software maintenance: The totality of activities required to provide cost-effective support to soft ware.

- Software configuration management: The identification of the configuration of a system at dis tinct points in time for the purpose of systematically controlling changes to the configuration, and maintaining the integrity and traceability of the configuration throughout the system life cycle.

- Software engineering management: The application of management activities-planning, coor dinating, measuring, monitoring, controlling, and reporting — to ensure that the development and maintenance of software is systematic, disciplined, and quantified.

- Software engineering process: The definition, implementation, assessment, measurement, man agement, change, and improvement of the software life cycle process itself. 
- $\quad$ Software engineering tools and methods: The computer-based tools that are intended to assist the software life cycle processes see Computer Aided Software Engineering, and the methods which impose structure on the software engineering activity with the goal of making the activity systematic and ultimately more likely to be successful.

- Software quality management: The degree to which a set of inherent characteristics fulfills the requirements.

When we discuss the future direction of software engineering contribution, there are great opportunities offered by software engineering discipline to the research community, industry practitioner, knowledge worker and global society. In term of future direction of Software Engineering, this field contributes into the growth software engineer society through Certified Software Engineering Professional which is recognized in global market. Some experts foresee the growth of Software Engineering field could give significant impact for globalization.

\subsection{The Future Direction of Digital Storytelling}

In this modern day, storytelling has been carried out through a new forms, that is digital. From being an informal medium to educate toddlers in household, it has become a formal medium to educate students in learning institutions. Moreover, with the advancement of technology and the emergence of multimedia elements such as audio, video, animation, and graphic; stories have taken a new form but keeping it original purpose which is to share knowledge and wisdom. This new form of storytelling has been acknowledged as digital storytelling (DST) (Banaszewski, 2005; Lambert,2006; Robin,2006; Ohler,2008). According to Porter (2004), DST combines the art of traditional storytelling with multimedia elements such as images, graphics, music, and audio in order to craft a personally voiced narrative. As for Robin (2014), he states that DST is a combination of the art of storytelling with different multimedia elements, including audio, video, graphic and Web publishing. However it is defined, DST is undeniably a new evolution of storytelling that is going to keep passing down the story from one generation to the next, and it is here to stay. This is due to the fact that modern day people are well exposed to technology and digital media. The other great advantage of DST is that it can be shown online (Lowenthal, 2009). Since it is digital, the stories can be uploaded to any free online video sharing and viewing repositories such as YouTube. 
The accessibility through internet has made the digital stories not just reachable by local but also able to be broadcasted to global audience. This new form had eventually given storytelling a larger platform and greater audiences to be interact with. According to Miller (2008), element of interactivity in digital stories has given the audience to be the co-creator of the story. In other words, the story is no more linear but is more malleable. Interactive in DST makes different outcomes of story possible. In classroom, DST not only would engage them on the topic but also may indirectly sharpen their literacy skills. Lowenthal (2009) states that with the involvement of DST in classroom, teacher can cultivate students' involvement in the classroom. According to Figure and Burson (2010), students are able to learn writing and digital imagery skills through the given assignment of producing digital story. Students who involve in the production of digital stories are exposed to multiple literacy skills, including: research skills, writing skills, organization skills, technology skills, presentation skills, interview skills, problem solving skills and assessment skill (Robin, 2006).The benefits of DST are abundance and beyond the frame of the article. However, with the selected few advantages of DST discussed, it is hoped that they become the beacon to enlighten us on the massive potential of DST. Finally, it is worth considering that the DST is not just able to transmit knowledge, wisdom, and information, but it also affects student literacy in the digital era.

\subsection{The Future Direction of Computer Generated Imagery}

Computer generated imagery or known as CGI is the application of the computer graphic or visual scenes that could be dynamic or static, and could be two-dimensional (2D) or three-dimensional (3D), however, the term "CGl" is most commonly used to refer to 3D computer graphics and has been used in films production, television programs, commercials and simulators by manipulating the 3D computer models to the virtual through few of the processes such as modelling, sculpting, texturing and rendering in order to create "virtual world".

CGI is used for visual effects in any films and commercial production because of the quality is often higher and effects are more controllable than other more physically based processes, such as constructing miniatures for effects shots or hiring extras for crowd scenes, and because it allows the creation of images that would not be feasible using any other technology. Furthermore, the process also allows a single artist to produce content without the use of actors, expensive props or sets and sophisticated special make-up tricks. Lev Manovich (2006) said the evolution of CGI had led to the emergence of virtual cinematography in the 1990s where runs of the simulated camera were not constrained by the laws of physics anymore.

According to Michele Pierson. (1999), digital technologies have not just transformed the film productions at the level of technical processes only, but have also transformed the people who engage in the production of films physically and mentally. CGI of film making is not only depending on the technologies and the technical of the 3D but also requiring engagement from the artists in their professional skills of 3D modelling, and ideas. 


\subsection{The Future Direction of Mobile Games}

The word ludology itself comesfrom the Latin word "ludus" meaning game (Frasca, 1999; 2003). According to the Maigaard (1950), ludology is the science of games and a part of sociology and the sciences concerned. Game studies is an interdisciplinary area of study at the cutting edge of computer science, psychology, sociology, anthropology, philosophy, arts and literature, media studies, communication, theology, and more to design and build the interactive games. In recent years, the game studies are not only applied to entertainment and electronic industries but also use of concepts and technologies derived from games for non-entertainment purposes, such as economics, medicine, engineering and the military. Based on the explanation of Rohlfshagen(Aron, 2011, 6 June),games are usually seen as a valuable test-bed for new technologies in computational intelligence as they are well defined yet very challenging. Examples of the major game categories include mobile games, computer games and video games. The mobile game industry is currently one of the most attractive and profitable industries in the world.

For instance, the Angry Birds is a very popular mobile game, created by Rovio Entertainment as shown in Figure 1.This game has been downloaded more than 100 million times since it is released in 2009. According to Dredge (2014, April 28) and Saarinen, Teivainen, Mäntylä \& Lehtikuva (2014, April 28), the four-year average Angry Birds revenue from 2010 to 2013 was 97.575 million euros as shown in Figure 2. In addition, Rovio reported revenues of 156 million euros in 2013 , a $2.4 \%$ increase over the 152.2 million euros generated in 2012 and significantly exceeding the previous records75.6 and 6.5 million euros generated in 2011 and 2010 respectively. Furthermore, Figure 3 shows the information on the mobile gaming revenue in the United States (US) from 2010 to 2012 with forecast until 2017. The US mobile gaming revenue is expected to increase from 1.36 billion US dollars in 2012 to 3.77 billion in 2017, a $63.93 \%$ increase (Statista, 2014). The 2012 sales figures are impressive, especially the sharp increase of number of the smartphone and tablet users, and more significantly, looking ahead, the mobile game industry shows no signs of slowing down. As a result, the mobile gaming has become a multi-billion dollar a year industry. It is a highly attractive avenue for continued investment. 


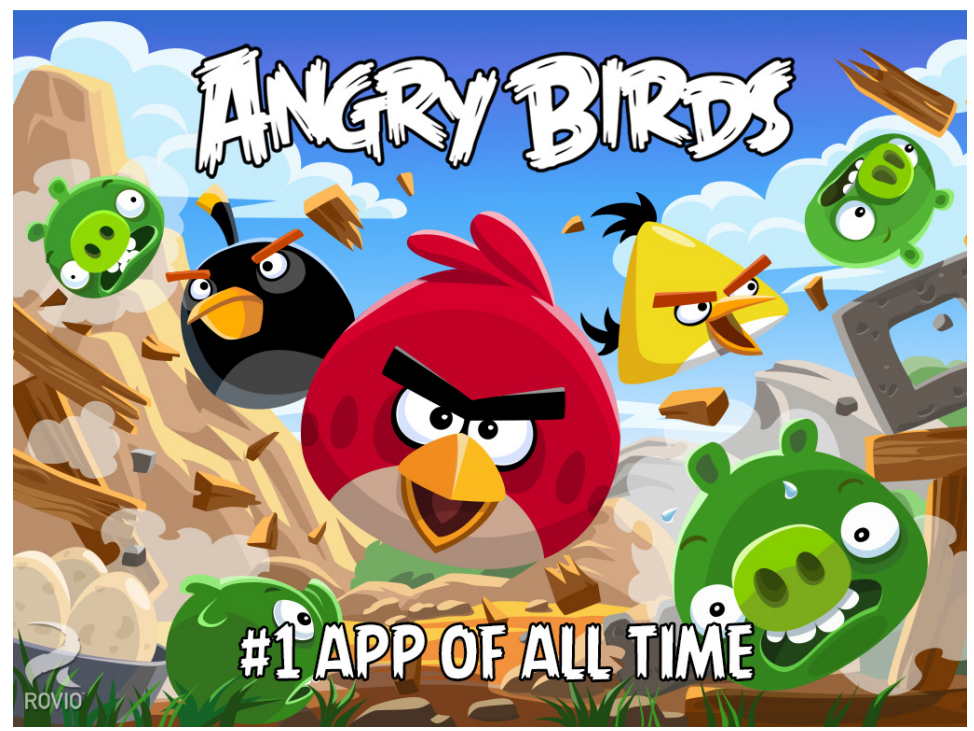

Figure 1: Angry Birds Rio from Rovio Entertainment Ltd.

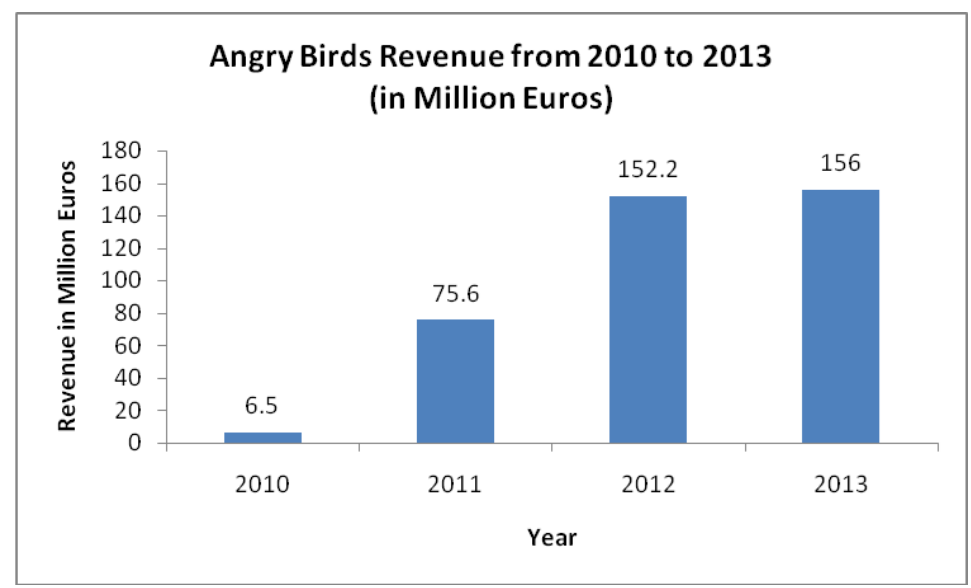

Figure 2: Angry Birds Revenue from 2010 to 2013 (in Million Euros) 


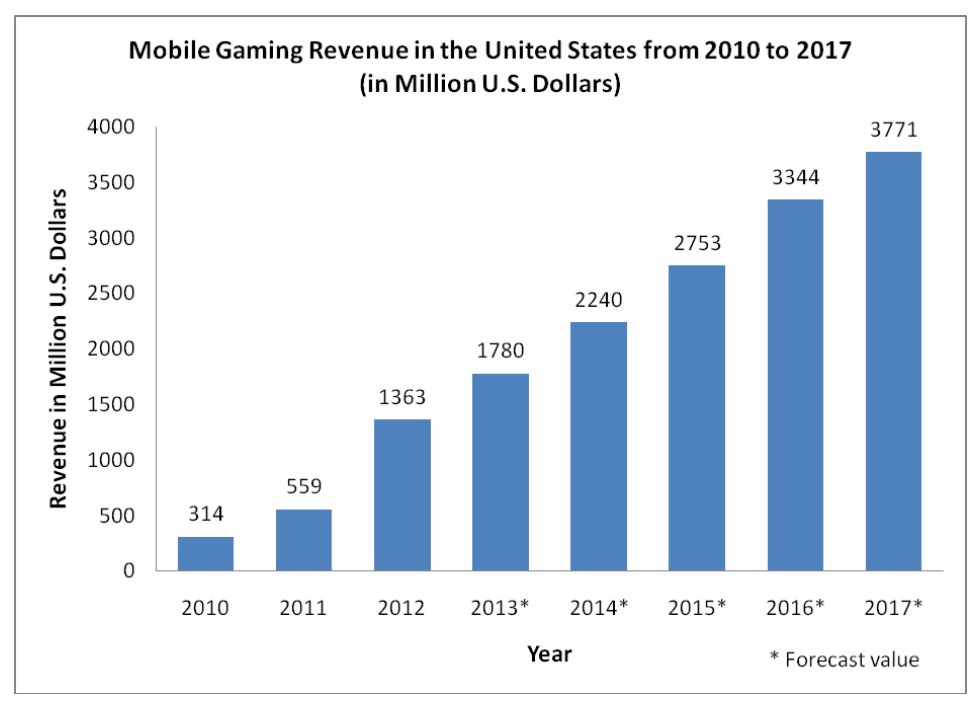

Figure 3: Mobile Gaming Revenue in the United States from 2010 to 2017 (in Million U.S. Dollars)

\subsection{The Future Direction of Intelligent Tutoring Systems}

The field of Intelligent Tutoring Systems that starts in early 1970s examines related research areas such as Artificial Intelligence, Computer Science, Cognitive Science and Education to build intelligent agents that can tutor students in computer-aided learning. Traditional computer-aided learning systems support students by providing predefined solutions or actions. These types of help are useful for some students learning lessons with well-defined and simple learning activities. It is not easy, however, to support students with complex learning activities because of the difficulties to predefine all possible solutions or actions (Hafidi \& Bensebaa, 2013).

Recent research in Intelligent Tutoring Systems makes an effort to study how to make the pedagogical agent more adaptive to each student by providing individualised support. The agent needs to have sufficient knowledge of how to teach and is able to reason to behave intelligently. To be able to teach sufficiently, a tutor needs to have the domain knowledge (Vihavainen, Airaksinen \& Watson, 2014), knowledge about each individual student (Reinecke \& Bernstein, 2013), and knowledge of teaching strategies. When interacting with students, human or computer teachers need to know how to communicate with each student to teach and give feedback (Rahati \& Kabanza, 2010).

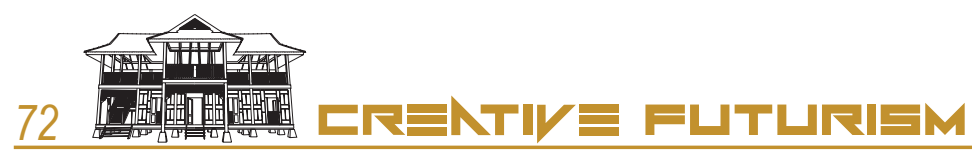


The behaviour of the intelligent agent is normally defined in terms of the types of teaching knowledge it has to solve problems in teaching and learning activities. To behave intelligently when teaching, the agent uses these models:
a. Pedagogical model - contains knowledge of how to teach.
b. $\quad$ Domain model - contains knowledge of what to learn.
c. Student model - contains knowledge about the current state of each student.
d. Communication model - contains knowledge of how to interact with the student.

In teaching, the agent presents selected learning activities to a student that it believes as the most suitable to the specific student. The ability to select this activity is based on its pedagogical, domain and student models. Then the agent monitors the progress of the student with the learning activity and decides whether the solutions or answers provided by the student are correct, and whether to give support.

When compared to traditional computer-aided instructions, the agent is different because the computer programmers do not have to predefine actions to the input given by the students (Gulwani, 2014). Instead, the agent is able to generate output in real-time through reasoning based on the represented knowledge in the models. The agent is also able to update its knowledge of the student regarding his acquired knowledge or skills and respond accordingly (Walker et al., 2012).

Researchers have investigated various aspects of the models. Most Intelligent Tutoring Systems focus on the domain and student models. Some focus on communication models to study how students interact with computer using touch screen and natural languages. There are also agents that are developed to support a variety of learning strategies such as: step-by-step tutorial, suggesting the next lesson to learn and explaining new concepts (Chen \& Chen, 2013; Gulwani, 2014). Similarly, some agents are examined to teach specific domains; science, mathematics, computer science and arts. With the introduction of tablet computers into classrooms and the availability of fast wireless internet connections, several of these agents are used in classrooms and can change the way students learn (Tayeb, Mahnane, \& Trigano, 2013).

It is challenging for the agents to generate individualised support for each student who might perform various learning activities on daily basis (Zatarain-Cabada et. Al, 2013). The main requirement is to model domains, student behaviours and their mental states which cannot be easily defined and represented in computational models. For example, to provide support with an art lesson, the agent must be equipped with the knowledge of principles of art so that it can reason logically when interacting with the student. New advances in computer science, artificial intelligent and computer hardware are the main factors that lead the direction of research in Intelligent Tutoring Systems; i.e. to develop pedagogical agents that can teach more effectively. 


\subsection{The Future Direction of Human Computer Interaction}

Human computer interaction is also known as man-machine interaction. It is closely related to interface that is used as a medium of interaction between human and computer. The success of human and computer interaction can be illustrated by the success of a computer system function and benefit users through the medium of an interface provided. Functionality aspect of the interaction between human and computer system can be identified when it is utilized (B. Shneiderman and C. Plaisant, 2004). In addition, the usability aspects of the interaction also play an important role, in which it determines the success of system (Te'eni, Carey and Zhang, 2007). Whether, it is effective, efficient or satisfaction in achieving an objective of usage (J. Nielsen, 1994). However, success in the interaction between human and computer is subjective and it depends on many factors. The example is the existence of the approaches in technology can affect the interaction between human and computer such as user experience in interface design.

Interface is a key element in interaction between human and computer. It has become the medium of interaction for human and computer. Interface developed by consider the user's needs for interact with computers will make it a perfect interface, not difficult and suitable to use. Meanwhile, interface has a certain limit for the user to interact with a computer would make it difficult to use (Te'eni, Carey and Zhang, 2007).

User aspects in human computer interaction can be divided into three factors: physical, cognitive, and affective. Considering these factors in identifying interaction methods between human and computer are very important. Physical factor is the way users interact with the computer through the body (Chapanis, 1965). Cognitive factor is the method or the way users understand computer and interaction so that they can adapt for use and then receive output produced (Norman, 1986). Meanwhile, the affective factor is the way that the computer can affect users through excitement experience that offered with focus on changing user attitudes and emotions. User will continue to use the computer in the next time (Te'eni, Carey and Zhang, 2007).

Input through the physical is one of the main factors considered in the development of an interface for human computer interaction. Physical factors can be categorized based on the human senses of vision, audition and touch (Te'eni, Carey and Zhang, 2007). The sense of vision is input through the physical factors that most frequently used (Greenstein, 1997 and Myers, 1998). Keyboard, mouse, touch screen panels, graphic tablets, trackballs, and pen-based input are tools that are based on the sense of vision (Shneiderman, 1998 and Murata 1991). It needs users to look at the interface and interact with the computer using the tools. Next, through the vision-based input device, the outputs produced are a visual display and printing equipment (Nielsen, 1994). Input by audition is using special equipment for speech recognition (Rabiner, 1993).

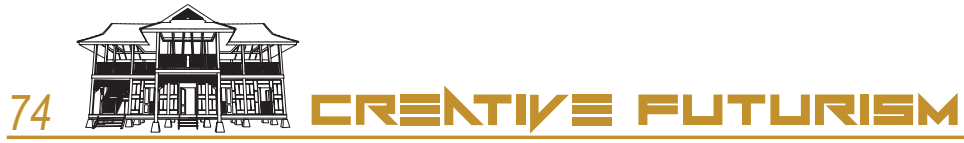


The output produced is in the form of messages of speech and non-speech signals. GPS device is technologies generated using this approach. Finally, input via touch is the most difficult and the use of expensive equipment for the development of an interface (Robles-De-La-Torre, 2006). The method used is to detect the skin and muscles through touch, pressure and vibration. It often used for the development of virtual reality (Vince, 2004) and aids for the disabled people (Iwata, 2003). Now, the combination of the three human senses in technology has been practiced. Such as, wireless devices in networking and virtual reality in animation (Yacoub, 2002; McMenemy and Ferguson, 2007).

In order to pursue the development of technology in line with the economic level, the design of the interaction between human and computer should be more considerate on the ease of use, more attractive and satisfaction experience to users. Some examples of human, computer and interaction development are a typewriter. The tool evolution in terms of the interaction has change the way of interaction and device itself through the creation of keyboard, touch screen, and voice command to generate a text (Riva, Vatalaro, Davide and Alaniz, 2005).

Intelligent aspects are necessary in the development of human computer interaction design in a new generation. With the intelligent aspect, it will make the design of interaction between human and computer become active compared with non-intelligent aspect. Situations that require intelligent aspect is in producing an interface for users to interact with the systems (Maybury and Wahlster, 1998) and the method of how the interface can provide interaction between the users and the systems (Kirlik, 2006). Applications of intelligent aspects in the interface for the users to interact with the systems are to consider the user perception and response as accurate as possible and appropriate (Oviatt et al., 2000). However, the application of intelligent aspects in human interaction with the system through the interface is to consider the cognitive aspect and level of affective on the activities of the user when they interact (Te'eni, Carey and Zhang, 2007).

Thus, interaction, human and computer factors are an important element to be considered in order to pursue the development of the technology and time changes. Users' ability factor in interaction with computers through physical, cognitive and affective is an initial step that should be given attention and detailed study so that the improvement will contribute to the next stage. In addition, the intelligent aspects should also be taken into consideration in ensuring the interface development and interaction that is offered to the user to practice will be more effective in dissemination of information and the objectives of the use and development of the system will be achieved. 


\subsection{Conclusions}

The creativity and innovation in cyberology that emphasizes the important roles of universities, industry players, government agencies and non-government agencies in emerging knowledge to enhance human capital endeavors as catalysts spur new knowledge and intellectual richness. The ultimate objects of this paper are to provide the ideas for the future related study and practical basis for cyberology. 


\section{REFERENCES}

David McCandless (2009). Information is Beautiful (New Edition). Collins: USA. ISBN 9780007294664.

Jason Lankow , Josh Ritchie \& Ross Crooks (2012). Infographics: The Power of Visual Storytelling Paperback. John Wiley \& Sons:USA. ISBN13: 9781118314043

Martin Toseland \& Simon Toseland (2012). Infographica: The World As You Have Never Seen It Before. Quercus Publishing Plc:USA. ISBN13: 9781780877570

Mark Simiciklas (2012). The Power of Infographics: Using Pictures to Communicate and Connect with your audience. Quercus Publishing PIc:USA. ISBN13: 9780789749499

Nathan Yau (2013). Data Points: Visualization That Means Something. John Wiley \& Sons:USA. ISBN13: 9781118462195

Randy Krum (2013). Cool Infographics: Effective Communication with Data Visualization and Design. John Willey \& Sons:USA. ISBN13: 9781118582282

Peter Naur and Brian Randell, Report on a conference sponsored by the NATO SCIENCE COMMITTEE Garmisch, Germany, 7th to 11th October 1968.

Sommerville Ian (2008). Software Engineering (7 ed.). Pearson Education . ISBN 978-81-7758-530-8

Randell, Brian (10 August 2001). "The 1968/69 NATO Software Engineering Reports". Brian Randell's University Homepage. The School of the Computer Sciences, Newcastle University.

Boehm (1981). Software Engineering Economics. Prentice-Hall. ISBN 0-13-822122-7.

Humphrey, Watts S. (1989). Managing the Software Process. Addison-Wesley.ISBN 0-201-18095-2.

ISO/IEC TR 19759:2005, Software Engineering -- Guide to the Software Engineering Body of Knowledge (SWEBOK)

Abran, Alain; Moore, James W.; Bourque, Pierre; Dupuis, Robert; Tripp, Leonard L. (2004). Guide to the Software Engineering Body of Knowledge. IEEE. ISBN 0-7695-2330-7.

Banaszewski, T. M. (2005). Digital storytelling: Supporting digital literacy in grades 4-2. Master of Science in Information Design and Technology Thesis, Georgia Institute of Technology, Atlanta, Georgia. 
Figg, C. \& Burson,J. (2010)Chapter Six: Multimedia and DGI: more Project Creation. Raleigh, NC: Lulu Enterprises, Inc.

Lambert,J. (2006)Digital storytelling: Capturing lives, creating community, 2nd ed. Berkelay, CA: Digital Diner Press.

Lowenthal, P. (2009) "Digital storytelling in education: An emerging instituional technology," in Story circle: Digital storytelling around the world, J. Hartley and K. McWilliam, Eds., First ed West Sussex: WileyBlackwell, pp. 252-259.

Miller, C. H. (2008). Digital storytelling: a creator's guide to interactive entertainment (2nd Ed.) Burlington,MA: Focal Press.

Ohler,J. (2008)Digital storytelling in the classroom: New media pathways to literacy, learning, and creativity. Thousand Oaks, CA: Corwin Press.

Porter, B. (2004). Digitales: The art of telling digital stories. Sedalia, CO: bjpconsulting.

Robin,B. (2006) "The Educational Uses of Digital Storytelling," in Society for Information Technology \& Teacher Education International Conference 2006, Orlando, Florida, USA, pp. 709-716.

Robin, B. (2014) ABOUT DIGITAL STORYTELLING:What is Digital Storytelling? Retrieved 6 August 2014 from: http://digitalstorytelling.coe.uh.edu/page.cfm?id=27\&cid=27

Lev Manovich. (2006), Animation published by SAGE publication: 1; 25

Michele Pierson. (1999) “No Longer State-of-the-Art: Crafting a Future for CGI." Wide Angle 29-47. Project MUSE. Web. 6 Aug. 2014

Frasca, G. (2003). Simulation versus Narrative: Introduction to Ludology. In Wolf, M. J. P., \& Perron, B. (Eds.), The Video Game Theory Reader (pp.221-235). New York: Routledge.

Frasca, G.(1999).Ludology Meets Narratology: Similitude and Differences between (Video) Games and Narrative. Retrieved from http://www.ludology.org/articles/ludology.htm

Maigaard, P. (1950). About Ludology. Proceedings of the International Congress of Sociology (pp. 362373).

Aron, J. (2011, 6 June). Al Programs Do Battle in Ms Pac-Man.NewScientist. Retrieved fromhttp://www. newscientist.com/blogs/onepercent/2011/06/ms-pac-man-vs-ghosts.html

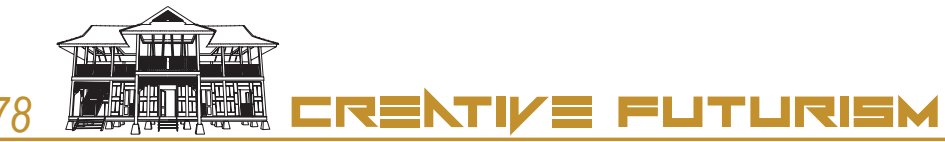


Statista. (2014). Mobile Gaming Revenue in the United States from 2010 to 2017 (in Million U.S. Dollars). Retrieval August 7, 2014, from http://www.statista.com/statistics/269831/mobile-gaming-revenue-in-theunited-states/

Dredge, S. (2014, April 28). Angry Birds Publisher Rovio Reveals Its Growth Stalled in 2013. theguardian.com. Retrieved from http://www.theguardian.com/technology/2014/apr/28/angry-birds-rovio-financialresults-2013

Saarinen, J., Teivainen, A., Mäntylä, K., \& Lehtikuva. (2014, April 28). Rovio Earnings Halved in 2013. Helsinki Times. Retrieved fromhttp://www.helsinkitimes.fi/business/10350-rovio-earnings-halved-in-2013. html.

Walker, E., Rummel, N., Walker, S. \& Koedinger, K. R. (2012). Noticing relevant feedback improves learning in an intelligent tutoring system for peer tutoring, ITS'12: Proceedings of the 11th international conference on Intelligent Tutoring Systems.

Rahati, A. \& Kabanza, F. (2010). Persuasive dialogues in an intelligent tutoring system for medical diagnosis, ITS'10: Proceedings of the 10th international conference on Intelligent Tutoring Systems - Volume Part II , Volume Part II

Gulwani, S. (2014). Example-based learning in computer-aided STEM education, Communications of the ACM , Volume 57 Issue 8.

Vihavainen, A., Airaksinen, J. \& Watson, C. (2014) A systematic review of approaches for teaching introductory programming and their influence on success, ICER '14: Proceedings of the tenth annual conference on International computing education research.

Gulwani, S. (2014). Applications of program synthesis to end-user programming and intelligent tutoring systems, GECCO Comp '14: Proceedings of the 2014 conference companion on Genetic and evolutionary computation companion.

Hafidi, M. \& Bensebaa, T. (2013). Development of an adaptive and intelligent tutoring system by expert system, International Journal of Computer Applications in Technology, Volume 48 Issue 4.

Chen, Z. \& Chen, S. Y. (2013). A surrogate competition approach to enhancing game-based learning, Transactions on Computer-Human Interaction (TOCHI), Volume 20 Issue 6. 
Zatarain-Cabada, R., Barrón-Estrada, M. L., Olivares Camacho, J. L. \& Reyes-García, C. A (2013). Integrating Learning Styles and Affect with an Intelligent Tutoring System, MICAI '13: Proceedings of the 2013 12th Mexican International Conference on Artificial Intelligence, Publisher: IEEE Computer Society.

Tayeb, L. M., Mahnane, L. \& Trigano, P. (2013). A Model for an Adaptive e-Learning Hypermedia System, International Journal of Information and Communication Technology Education, Volume 9 Issue 4.

Reinecke, K. \& Bernstein, A. (2013). Knowing what a user likes: a design science approach to interfaces that automatically adapt to culture, MIS Quarterly , Volume 37 Issue 2, Publisher: Society for Information Management and The Management Information Systems Research Center.

D. Te'eni, J. Carey and P. Zhang, Human Computer Interaction:

Developing Effective Organizational Information Systems, John Wiley \& Sons, Hoboken (2007

J. Nielsen, Usability Engineering, Morgan Kaufman, San Francisco (1994).

A. Chapanis, Man Machine Engineering, Wadsworth, Belmont (1965).

D. Norman, "Cognitive Engineering", in D. Norman and S. Draper (eds), User Centered Design: New Perspective on Human- Interaction, Lawrence Erlbaum, Hillsdale (1986).

J.S. Greenstein, "Pointing devices", in M.G. Helander, T.K. Landauer and P. Prabhu (eds), Handbook of Human-Computer Interaction, Elsevier Science, Amsterdam (1997).

B.A. Myers, "A brief history of human-computer interaction technology", ACM interactions, 5(2), pp 44-54 (1998).

B. Shneiderman, Designing The User Interface: Strategies For Effective Human Computer Interaction (3rd edition) Addison Wesley Longman, Reading (1998).

A. Murata, "An experimental evaluation of mouse, joystick, joycard, lightpen, trackball and touchscreen for Pointing - Basic Study on Human Interface Design", Proceedings of the Fourth International Conference on Human-Computer Interaction 1991, pp 123-127 (1991).

L.R. Rabiner, Fundamentals of Speech Recognition, Prentice Hall,

Englewood Cliffs (1993).

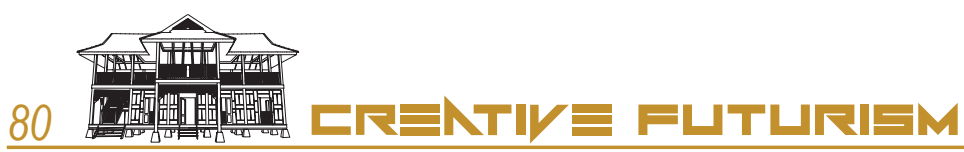


G. Robles-De-La-Torre, "The Importance of the sense of touch in virtual and real environments", IEEE Multimedia 13(3), Special issue on Haptic User Interfaces for Multimedia Systems, pp 24-30 (2006).

J. Vince, Introduction to Virtual Reality, Springer, London (2004).

H. Iwata, "Haptic interfaces", in J.A. Jacko and A. Sears (eds), The

Human-Computer Interaction Handbook: Fundamentals, Evolving Technologies, and Emerging Application, Lawrence Erlbaum Associates, Mahwah (2003).

M.D. Yacoub, Wireless Technology: Protocols, Standards, and Techniques, CRC Press, London (2002).

K. McMenemy and S. Ferguson, A Hitchhiker's Guide to Virtual Reality, A K Peters, Wellesley (2007).

G. Riva, F. Vatalaro, F. Davide and M. Alaniz, Ambient Intelligence: The Evolution of Technology, Communication and Cognition towards the Future of $\mathrm{HCl}$, IOS Press, Fairfax (2005).

M.T. Maybury and W. Wahlster, Readings in Intelligent User Interfaces,Morgan Kaufmann Press, San Francisco (1998).

A. Kirlik, Adaptive Perspectives on Human-Technology Interaction, Oxford University Press, Oxford (2006).

S.L. Oviatt, P. Cohen, L. Wu, J. Vergo, L. Duncan, B. Suhm, J. Bers, T. Holzman, T. Winograd, J. Landay, J. Larson and D. Ferro, "Designing the user interface for multimodal speech and pen-based gesture applications: state-of-the-art systems and future research directions", Human-Computer Interaction, 15, pp 263-322 (2000). 